\title{
Fasting hypochlorhydria with Gram positive gastric flora is highly prevalent in healthy old people
}

\author{
E Husebye, V Skar, T Høverstad, K Melby
}

\begin{abstract}
Fifteen healthy old people mean age 84 years (range 80-91 years), were examined to assess the effect of advanced age on the microecology of the upper gastrointestinal tract. Twelve of $15(80 \%)$ were hypochlorhydric with $\mathrm{pH} 6.6$ $(0.3)$ (mean (SEM) and a mean bacterial count of $10^{8}$ colony forming units (CFU) per $\mathrm{ml}$ (range $\left.10^{5}-10^{10}\right)$ in fasting gastric aspirate. Normochlorhydric subjects had low counts $\left(\leqslant 10^{1}\right.$ CFU/ml). The microbial flora was dominated by viridans streptococci, coagulase negative staphylococci, and Haemophilus sp. Only one subject harboured significant concentrations of Gram negative bacilli with Escherichia coli $\left(10^{4-5} \mathrm{CFU} / \mathrm{ml}\right)$ and Klebsiella $\left(10^{4-5}\right)$. Strict anaerobes were not found. The total concentration of short chain fatty acids in gastric aspirate was $10.6(2.9) \mathrm{mmol} / \mathrm{l}$ (mean (SEM). Absence of significant, intraluminal fermentation of xylose to $\mathrm{CO}_{2}$ was shown by the ${ }^{14} \mathrm{C}$-d Xylose breath test, and ambulatory manometry showed preserved fasting motility pattern of the small intestine. Serum immunoglobulins were normal. Advanced age is accompanied by fasting hypochlorhydria and colonisation with mainly Gram positive flora in the upper gut. Other factors than old age and fasting hypochlorhydria are required for colonisation with Gram negative bacilli.
\end{abstract}

(Gut 1992; 33: 1331-1337)

Gastric juice from healthy fasted subjects harbours $\leqslant 10^{3}$ colony forming units (CFU) per $\mathrm{ml}^{1-3}$ and aspirate from the proximal small intestine contains $\leqslant 10^{5},{ }^{23}$ provided that gastric acidity is preserved. Gram positive organisms dominate, with lactobacilli, staphylococci, and fungi as the most common species. ${ }^{23}$ Enterobacteria are absent ${ }^{3}$ or present in low counts, but there may be anaerobes of oral origin. ${ }^{2}$

Host defence mechanisms are partly responsible for this selection and control of microbial growth. ${ }^{45}$ Gastric juice represents a barrier to microbes in saliva and ingested food, mainly by the bactericidal activity of hydrochloric acid. Accordingly, fasting gastric juice $\mathrm{pH}>3-4$ is accompanied by increasing concentrations of microbes in the stomach ${ }^{126-8}$ and proximal small intestine. ${ }^{278}$ In the absence of gastric acid, individuals usually harbour the same bacterial species, in similar concentrations, in aspirates from the stomach and proximal small intestine. ${ }^{78}$ A typical qualitative pattern of microbes accompanying hypochlorhydria has not been found. Colonic flora, defined as microbial species usually confined to the lower gastrointestinal tract in healthy individuals, is quite common after Bilroth II partial gastrectomy, ${ }^{67}$ less com- mon after vagotomy, ${ }^{69}$ and present in about every other patient with pernicious anaemia ${ }^{278}$ and hypogammaglobulinaemia with achlorhydria. ${ }^{10}$ These clinical conditions exhibit rather complex and heterogeneous pathophysiology that may affect intestinal flora through changes in defence mechanisms other than gastric acidity. ${ }^{11}$ The importance of changed motility for microbial colonisation has been shown after gastric surgery, ${ }^{679}$ and drainage is probably just as important in other clinical conditions with hypochlorhydria.

Ageing is accompanied by an increasing prevalence of gastritis ${ }^{12}$ and declining output of gastric acid, ${ }^{13}$ whereas contradictory findings have been reported for gastric emptying. ${ }^{14}$ is It is currently believed that absence of gastric acid can lead to microbial growth, including that of Gram negative bacilli, in the upper gut. ${ }^{16}$ As the clinical consequences of bacterial overgrowth are associated with presence of these species, and anaerobes in particular, ${ }^{16}$ age related hypochlorhydria may represent a pathogenetic factor in the elderly. Reports of bacterial overgrowth without a blind loop in the elderly have brought this issue to current interest, ${ }^{17}$ and the need for studies on intestinal flora and factors regulating microbial growth in ageing has recently been emphasised. ${ }^{18}$

This prospective study examined gastric $\mathrm{pH}$, microbial flora, and metabolic markers in the upper gastrointestinal tract of healthy old $(>80$ years) people. Concomitant analyses of small intestinal motility and serum immunoglobulins are presented to illustrate the relationship between changes in proximal intestinal flora and major host defence mechanisms.

\section{Methods}

SUBJECTS

Fifteen healthy volunteers with a mean age of 84 years (range 80-91) years took part in the study. There were seven men (mean 84 years) and eight women ( 83 years). The mean weight was $72 \mathrm{~kg}$ (range 62-80 kg) for men and $56 \mathrm{~kg}$ (range 43-63 $\mathrm{kg}$ ) for women. These subjects were selected from a random sample of individuals above 75 years carefully examined to determine the prevalence of dementia in the general population. ${ }^{19}$ People without signs of dementia, who looked lively and in good clinical condition and who had no diseases or symptoms that interfered significantly with daily activities or natural functions were invited to participate.

The entrance criteria included absence of gastrointestinal disorders; previous gastric, bilary, or small intestinal surgery; and endocrine, systemic, neuromuscular, liver, or kidney
A, Rikshospitalet, Oslo, Norway

Correspondence to: Dr Husebye, Department of Medicine, Ullevål Hospital, N-0407 Oslo 4, Norway.

Accepted for publication 15 March 1992 
disease. Antibiotics had not been taken in the two months before the study. Laboratory tests are given as means and $95 \%$ confidence intervals $(\mathrm{CI})$ with the number of individuals with values below (L) and above $(\mathrm{H})$ the reference limits in brackets: haemoglobin $14 \cdot 1 \mathrm{~g} / 100 \mathrm{ml}(13 \cdot 6-14 \cdot 7$ $\mathrm{g} / 100 \mathrm{ml}$ ); whole blood folic acid $437 \mathrm{nmol} / 1$ (334-540 nmol/l) $(1 \mathrm{H})$; serum vitamin B12 238 $\mathrm{pmol} / \mathrm{l}$ (159-318 pmol/l) (3L). Intrinsic factor antibodies were not detected, while low, unspecific titres of antibodies against parietal cells were present in four subjects. Further details' regarding clinical data and laboratory tests have been given elsewhere. ${ }^{1920}$ All subjects gave their written informed consent, and the study was approved by the ethics committee for Health Region 1 in Norway.

Sixteen asymptomatic healthy laboratory workers with a mean age of 43 years (range 32-68 years) served as controls for the 14C-d Xylose breath test. Their mean weights were $70 \mathrm{~kg}$ (range 55-83 kg) for men $(\mathrm{n}=9)$, and $61 \mathrm{~kg}$ (range $55-70 \mathrm{~kg})$ for women $(\mathrm{n}=7)$.

PROTOCOL

In the morning, after an overnight fast from 6 $\mathrm{pm}$, a sterile polyethylene orogastric tube with internal diameter $3.0 \mathrm{~mm}$ (UNO Plast $\mathrm{A} / \mathrm{S}$, Hundested, Denmark) was introduced. A 4\% lidocain aerosol spray was applied to the throat beforehand. To ensure correct tube position, aspiration was performed with the tip a minimum of 40 and a maximum of $50 \mathrm{~cm}$ from the teeth. Five to $10 \mathrm{ml}$ of gastric juice were aspirated by sterile syringe and air bubbles removed. The syringe was closed by a cap and taken to the laboratory immediately for incubation ( $<10$ minutes). One $\mathrm{ml}$ was used for bacteriological samples, $0.5 \mathrm{ml}$ for $\mathrm{pH}$ measurement, and the remainder was divided into $1 \mathrm{ml}$ portions and frozen immediately at $-70^{\circ} \mathrm{C}$ for subsequent analyses of short chain fatty acids (SCFA). Venous blood samples were collected after the intubation and frozen at $-70^{\circ} \mathrm{C}$.

\section{GASTRIC ACIDITY}

The $\mathrm{pH}$ in aspirates was measured by glass electrode (pHm 62 Radiometer, Copenhagen) within two hours, after adjustment with standard buffers.

Gastric intubation and aspiration induce duodenogastric reflux. A methodological study was undertaken to estimate approximately the magnitude of this bias and to establish the reliability of $\mathrm{pH}$ measurement in gastric aspirates. Twenty nine consecutive outpatients referred for gastroscopy, who had had no previous gastric surgery or taken medication that inhibits the secretion of gastric acid, were examined (14 men and 15 women, aged mean 53 years (range 18 to 84 years)). Five $\mathrm{ml}$ of gastric juice were aspirated through an internal sterile polyethylene catheter after the endoscope entered the stomach. After appropriate procedures, aspiration was repeated in the same way but with a new catheter before removing the endoscope. In the meantime vomiting was noted, as was the colour of the

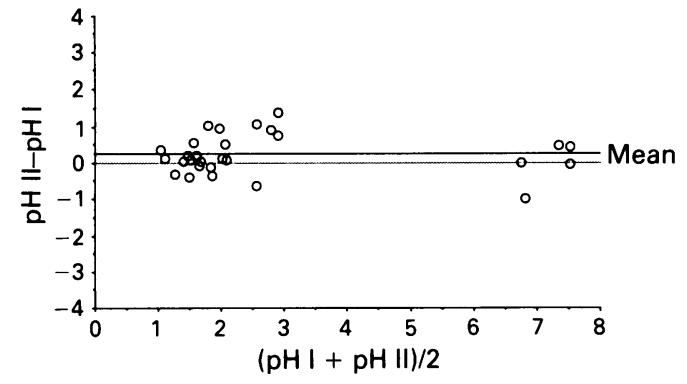

Figure 1: $p H$ in duplicate aspirates of gastric juice taken during endoscopy - at the beginning ( $p H I)$ and after having performed the examination with appropriate procedures ( $p H$ II). The mean difference between the two measurements is indicated by the upper horizontal line, and no difference by the zero line. Twenty nine consecutive outpatients, indicated by circles $(\mathrm{O})$.

gastric juice. Good reproducibility was found between the two samples (Fig 1). There was a slight increase in $\mathrm{pH}$ of $0.22(0.02,0.42)$ (mean $95 \%$ CIs) (range -0.99 to 1.39 ). The presence of bile colour or vomiting did not correlate with the $\mathrm{pH}$ level or difference. The average of the two measurements in individuals with $\mathrm{pH}$ less than four (24 outpatients), was pH 1.87 (0.54) (mean (SD)). Accordingly, the cut off level was set at $\mathrm{pH} 3$ (mean+2SD). The terms low gastric $\mathrm{pH}$ and fasting normochlorhydria are used synonymously for $\mathrm{pH} \leqslant 3$ in fasting gastric aspirate, and fasting hypochlorhydria for $\mathrm{pH}>3$.

\section{BACTERIOLOGICAL METHODS}

One $\mathrm{ml}$ of the aspirate was added to a sterile tube with $9 \mathrm{ml}$ prereduced thioglucolate broth and $1 \%$ glucose. A series of 10 fold dilutions was made with the same broth. Sterile Durham tubes $(1 \cdot 8$ $\mathrm{ml}$ ) were placed upside down within the broth tubes to detect the production of gas. Anaerobiosis was secured by the pyrogalol method, ${ }^{21}$ and finally, the tubes were closed by sterile airtight caps and incubated at $37^{\circ} \mathrm{C}$ for 48 hours. From the first tube, $0.001 \mathrm{ml}$ was inoculated onto blood agar, lactose-bromthymol blue agar, and chocolate agar plates. In addition, $0.01 \mathrm{ml}$ was inoculated onto chocolate agar plate. These plates were incubated at $37^{\circ} \mathrm{C}$ in a moist $5 \% \mathrm{CO}_{2}$ atmosphere. After 48 hours, inoculation was performed from the first and last tubes with visible growth onto blood agar, lactose-bromthymol blue agar, and mannitol salt agar plates for aerobic growth. Two blood agar plates, to one of which had been added gentamicin $10 \mathrm{mg} / \mathrm{l}$, were incubated at $37^{\circ} \mathrm{C}$ in anaerobic jars (BBL GasPak Plus, Becton Dickinson \& Co, Cockeysville, $M D$, US) for 48 hours, while aerobic plates were inspected after 24 hours. Identification was performed according to conventional methods.

Visible bubbles of gas in the Durham tubes were noted, and the gas ratio was calculated as $\log _{10}$ to the concentration of microbes corresponding to the last tube with visible gas, divided by $\log _{10}$ to the total concentration of microbes. The term COL flora was used if enterobacteriacea, strict anaerobes of the bacteroides fragilis group, or Clostridium sp occurred in counts $\geqslant 10^{4}$ per $\mathrm{ml}$, and COL in brackets if counts were $<10^{4}$. Mainly Gram positive flora without the above mentioned COL species were denoted 


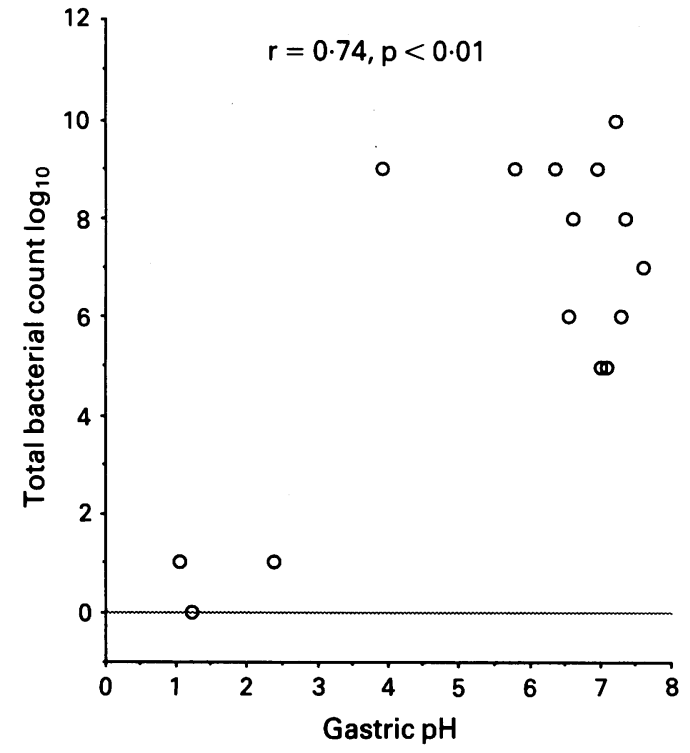

Figure 2: A scatter plot of $p H$ and total bacterial counts in fasting gastric aspirates from 15 healthy old people. The correlation coefficient with corresponding $p$ value is given.

URT flora (upper respiratory tract) with the same use of brackets.

METABOLIC ANALYSES

The ${ }^{14} \mathrm{C}$-d Xylose breath test was performed as described by Skar et $a l,{ }^{22}$ and short chain fatty acids (SCFA) were examined by gas chromatography as described by Høverstad et al. ${ }^{23}$

\section{SMALL INTESTINE MOTILITY}

Digital ambulatory manometry was undertaken as previously described by Husebye $e t a l,{ }^{24}$ and the results have been presented in detail elsewhere. ${ }^{20}$ During fasting, aborally migrating bands of regular phasic contractions (phase III) recur at intervals, intercepted by periods of silence (phase I), and irregular contractions (phase II). The cumulated phase III index is the sum of the duration (in minutes) of all phase III activities recorded after the intake of a standardised meal of $1700 \mathrm{~kJ}$ at $6 \mathrm{pm}$ until $7.25 \mathrm{am}$ the next day.

\section{BLOOD SAMPLES}

Gastrin was measured by radiommunossay (Becton Dickinsons \& Co, New York). ${ }^{2 \varsigma}$ Electrophoresis of plasma proteins with quantification of immunoglobulins and the blood tests for the old people were analysed at Department for Clinical Chemistry, Ullevål Hospital according to standard procedures.

\section{STATISTICS}

Data are presented as mean and (SEM) unless otherwise stated. Means are compared by Student's $t$ test for unpaired samples. Furthermore, Student's matched pair test and correlation techniques are applied. The reliability of $\mathrm{pH}$ in gastric aspirates is presented by the relation $(\mathrm{pH} 2-\mathrm{pH} 1) /[\mathrm{pH} 1+\mathrm{pH} 2) / 2],{ }^{26}$ and judged by testing the difference between the two measurements.

\section{Results}

GASTRIC ACIDITY AND SERUM GASTRIN

Twelve of the $15(80 \%)$ healthy old people were hypochlorhydric, with $\mathrm{pH} 6.6(0.3)$ in fasting gastric juice (Fig 2). The $95 \%$ CIs for the prevalence of fasting hypochlorhydria were $60 \%$, $100 \%$. Serum gastrin concentration were $88(31)$ $\mathrm{pmol} / \mathrm{l}$ (Table); $105 \mathrm{pmol} / \mathrm{l}$ (range 8 to 400 $\mathrm{pmol} / \mathrm{l})$ in hypochlorhydric individuals $(\mathrm{n}=12)$ and $21 \mathrm{pmol} / \mathrm{l}$ (range 12 to $35 \mathrm{pmol} / \mathrm{l}$ ) in the low $\mathrm{pH}$ group $(\mathrm{n}=3)$.

\section{GASTRIC MICROBIAL FLORA}

The total bacterial count was median $10^{7} \mathrm{CFU} /$ $\mathrm{ml}$; mean $10^{8}$ (range $10^{5}-10^{10}$ ) in hypochlorhydric individuals, and $\leqslant 10^{1}$ in the normochlorhydric subjects (Table, Fig 2). Fifty five per cent of the variation in the total bacterial count could be explained by gastric $\mathrm{pH}(\mathrm{r}=0.74, \mathrm{p}<0.005)$. A distinct pattern of microbial flora was present in the hypochlorhydric subjects (Table, Fig 3) with microbes belonging to the indigenous upper respiratory tract flora, mainly facultative Gram positives. Viridans streptococci was the dominant species, and coagulase negative staphylo-

Microbial flora, $\mathrm{pH}$, and short chain fatty acid (SCFA) concentrations in fasting gastric juice, and IgA and gastrin in serum of healthy old people

\begin{tabular}{|c|c|c|c|c|c|c|c|c|}
\hline $\begin{array}{l}\text { Subject } \\
\text { no }\end{array}$ & $\stackrel{p H}{(\log [H+])}$ & $\begin{array}{l}\text { Serum gastrin } \\
(p m o l / l)\end{array}$ & $\begin{array}{l}\text { Bacterial count } \\
\left(\log _{10} C F U / m l\right)\end{array}$ & Type of flora & $\begin{array}{l}\text { Last } \\
\text { dilution } \\
\text { with gas }\end{array}$ & Gas ratio $^{\star}$ & $\begin{array}{l}\text { Total } \\
\text { SCFA } \\
(\mathrm{mmol} / \mathrm{l})\end{array}$ & $\begin{array}{l}\text { Serum IgA } \\
(\mathrm{g} / \mathrm{l})\end{array}$ \\
\hline $\begin{array}{l}\text { B1 } \\
\text { B2 } \\
\text { B3 } \\
\text { B4 } \\
\text { B5 } \\
\text { B6 } \\
\text { B7 } \\
\text { B8 } \\
\text { B9 } \\
\text { B10 } \\
\text { B11 } \\
\text { B12 } \\
\text { B13 } \\
\text { B14 } \\
\text { B15 }\end{array}$ & $\begin{array}{l}7 \cdot 34 \\
7 \cdot 61 \\
5 \cdot 80 \\
7 \cdot 28 \\
2 \cdot 39 \\
7 \cdot 20 \\
7 \cdot 10 \\
6 \cdot 96 \\
6 \cdot 35 \\
6 \cdot 60 \\
1 \cdot 05 \\
1 \cdot 23 \\
3 \cdot 92 \\
6 \cdot 54 \\
7 \cdot 01\end{array}$ & $\begin{array}{r}20 \\
18 \\
14 \\
73 \\
15 \\
275 \\
31 \\
50 \\
255 \\
38 \\
12 \\
35 \\
8 \\
400 \\
75\end{array}$ & $\begin{array}{r}8 \\
7 \\
9 \\
6 \\
1 \\
10 \\
5 \\
9 \\
9 \\
8 \\
1 \\
0 \\
9 \\
6 \\
5\end{array}$ & $\begin{array}{l}\text { URT } \\
\text { URT } \\
\text { URT } \\
\text { URT+(COL) } \\
\text { (URT) } \\
\text { URT } \\
\text { URT } \\
\text { URT } \\
\text { URT } \\
\text { URT } \\
\text { (URT) } \\
\text { Sterile } \\
\text { COL } \\
\text { URT+COL } \\
\text { URT }\end{array}$ & $\begin{array}{l}0 \\
0 \\
4 \\
3 \\
0 \\
3 \\
1 \\
0 \\
0 \\
0 \\
0 \\
0 \\
8 \\
5 \\
0\end{array}$ & $\begin{array}{l}0 \\
0 \\
0 \cdot 4 \\
0 \cdot 5 \\
0 \\
0 \cdot 3 \\
0 \cdot 2 \\
0 \\
0 \\
0 \\
0 \\
0 \\
0 \cdot 9 \\
0 \cdot 8 \\
0\end{array}$ & $\begin{array}{r}8 \cdot 3 \\
7 \cdot 0 \\
2 \cdot 2 \\
11 \cdot 6 \\
2 \cdot 5 \\
5 \cdot 9 \\
37 \cdot 5 \\
21 \cdot 8 \\
31 \cdot 7 \\
8 \cdot 5 \\
4 \cdot 0 \\
1 \cdot 0 \\
2 \cdot 2 \\
5.9 \\
9 \cdot 1\end{array}$ & $\begin{array}{l}2 \cdot 9 \\
4 \cdot 1 \\
3 \cdot 4 \\
3 \cdot 4 \\
1.9 \\
4 \cdot 6 \\
4 \cdot 7 \\
4 \cdot 7 \\
0 \cdot 8 \\
2 \cdot 5 \\
3 \cdot 3 \\
4 \cdot 9 \\
0 \cdot 0 \\
2.9 \\
4 \cdot 1\end{array}$ \\
\hline $\begin{array}{l}\text { Mean } \\
\text { 95\% CIs }\end{array}$ & $\begin{array}{l}5 \cdot 60 \\
4 \cdot 4,6 \cdot 9\end{array}$ & $\begin{array}{l}88 \\
21 \cdot 2,154 \cdot 6\end{array}$ & $\begin{array}{l}6 \cdot 2 \\
4 \cdot 4,8 \cdot 0\end{array}$ & & $\begin{array}{l}1 \cdot 6 \\
0 \cdot 2,3 \cdot 0\end{array}$ & $\begin{array}{l}0 \cdot 2 \\
0.0,0.4\end{array}$ & $\begin{array}{l}10 \cdot 6 \\
+\cdot 5,16 \cdot 7\end{array}$ & $\begin{array}{l}3 \cdot 2 \\
4 \cdot 0,2 \cdot 4\end{array}$ \\
\hline
\end{tabular}

URT: upper respiratory tract flora; COL: colonic type of flora; ( ) indicates $<10^{2}$ colony forming units (CFU) per ml. For detailed definitions cf text. * The ratio: last dilution with gas/bacterial count. 


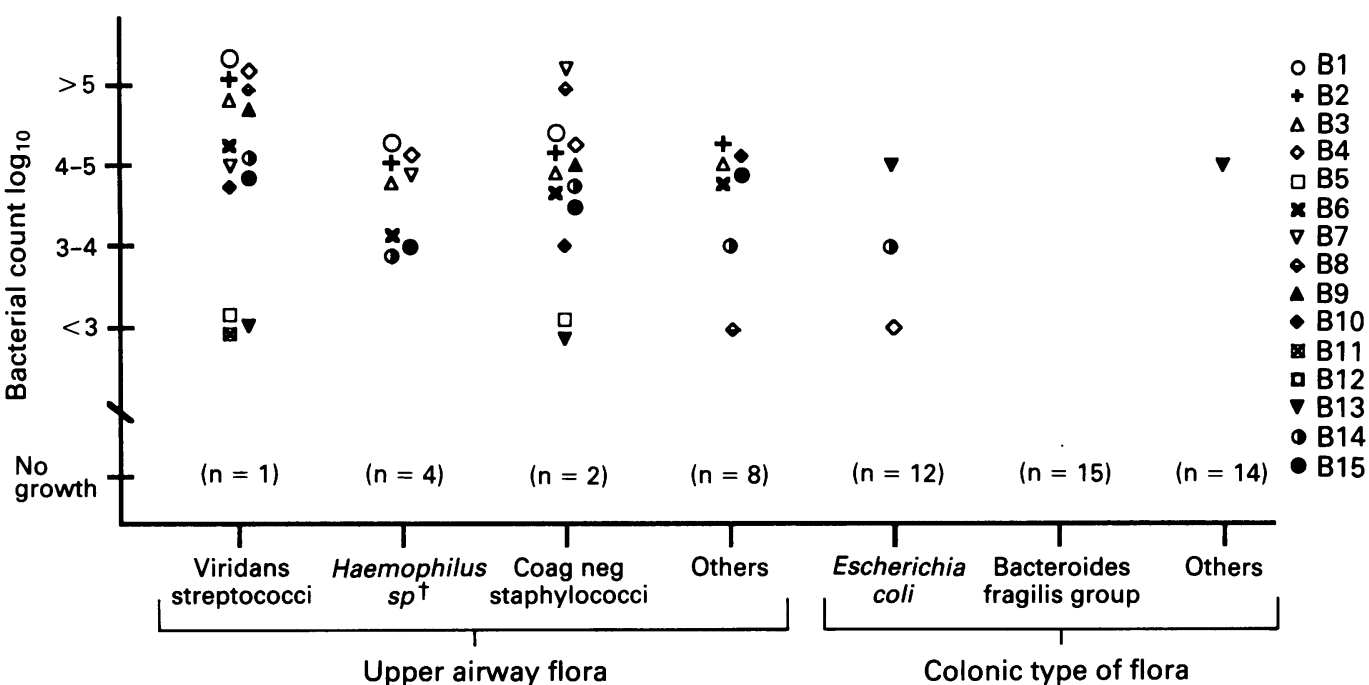

Figure 3: The presence of microbial species in gastric aspirates from 15 healthy old people $(B 1-15)$ is shown. The count for each bacterial species is indicated by the corresponding symbol for each individual. 'Others' include non-haemolytic streptococci, Moraxella sp and diphteroides for upper airway, and klebsiella for the colonic type of flora. $f$ For technical reasons, three samples were not cultured in the appropriate media.

cocci and Haemophilus sp were commonly present in counts exceeding $10^{3} \mathrm{CFU} / \mathrm{ml}$. In some subjects, non-haemolytic streptococci, Moraxella sp, and diphtheroids were recovered, and two subjects had low counts of Escherichia coli, outnumbered by URT flora. One individual had COL flora in gastric aspirate with $E$ coli $\left(10^{4-5}\right.$ $\mathrm{CFU} / \mathrm{ml})$ and Klebsiella $\left(10^{4-5}\right)$ as dominating species (B13). Strict anaerobes were not detected.

\section{GASTRIC MICROBIAL METABOLISM}

Gastric juice contained 10.6 (2.9) $\mathrm{mmol} / \mathrm{l} \mathrm{SCFA}$ (Table). The relative contributions of $\mathrm{C} 2 ; \mathrm{C} 3$; $\mathrm{iC} 4$; and $\mathrm{nC} 4$ were $86 \cdot 6 ; 12 \cdot 0 ; 0 \cdot 1$; and $1.5 \%$ of the total concentration, respectively. Subjects with low gastric $\mathrm{pH}$ had rather low concentrations, but no statistically significant correlation was found between SCFA and gastric $\mathrm{pH}$ or the total bacterial count. Very high concentrations

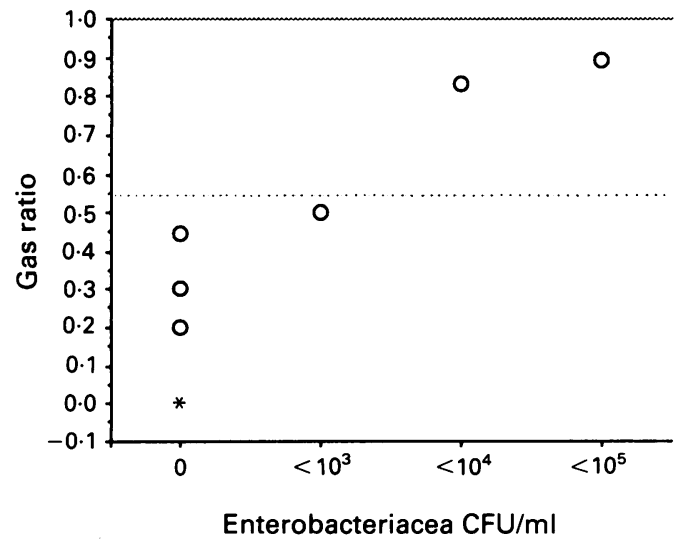

Figure 4: A scatter plot showing how the production of gas in vitro, expressed by the gas ratio, depends on the presence of enterobacteriacea in fasting gastric aspirates. Samples from 15 healthy old people are shown. The zig-zag line shows the upper asymptomatic value for the gas ratio, and the dotted line is mean $+2 S D$ for hypochlorhydric individuals with $<103 \mathrm{CFU} / \mathrm{ml}$ of enterobacteriacea. ${ }^{\star}$ Indicates overlap of nine observations. $C F U=$ denotes colony forming units. The gas ratio is defined in the method section.
( $>20 \mathrm{mmol} / \mathrm{l}$ ) were present in three individuals with URT flora, but no consistent relationship was found between the levels of SCFA and the type of gastric microflora (Table).

Production of gas from glucose under anaerobic growth conditions occurred in samples from six individuals (Table, Fig 4). The individual with COL flora had considerable gas production (B13), while slight to moderate production was seen in the remaining five. Gas production occurred in the presence of abundant URT flora (B3 and B6), but only in the initial steps of the dilutions, as reflected by low gas ratios in individuals with URT flora (Fig 4). Hypochlorhydric individuals with less than $10^{3} \mathrm{CFU} / \mathrm{ml}$ of $E$ coli had a gas ratio of $0 \cdot 14(0 \cdot 20)$ (mean (SD)), while the two individuals with higher concentrations of $E$ coli (B13 and B14) had gas ratios of 0.9 and $0 \cdot 8$, respectively.

INTESTINAL MICROBIAL METABOLISM

Intraluminal bacterial metabolism of xylose to $\mathrm{CO}_{2}$ was sparse, as practically similar levels of expired ${ }^{14} \mathrm{CO}_{2}$ were found in the healthy old people and controls, apart from one outlying observation (Fig 5). Cumulated expired ${ }^{14} \mathrm{CO}_{2}$ within the first 180 minutes were 8.0 and $6.1 \%$ of the dose in these groups respectively, a slight difference of borderline statistical significance $(p=0 \cdot 06)$. The old person with considerable fermentation of xylose (B13), indicating bacterial overgrowth of the small intestine, had COL flora in gastric juice. In individuals with URT flora $(\mathrm{n}=13)$, the expired ${ }^{14} \mathrm{CO}_{2}$ value was not related to total bacterial count $(\mathrm{r}=0 \cdot 3, \mathrm{p}=0 \cdot 4)$.

SMALL INTESTINAL MOTILITY

Ambulatory manometry showed preserved fasting motility with a median of 4 (range 2 to 6) migrating motor complexes during one night. The estimate for the cumulated phase III index was $28 \cdot 2$ minutes $(23 \cdot 2,33 \cdot 1$ minutes) ( $95 \%$ CIs), and minimum values were 17.5 minutes $(\mathrm{B} 6)$ and $17 \cdot 6$ minutes $(\mathrm{B} 13)$ 


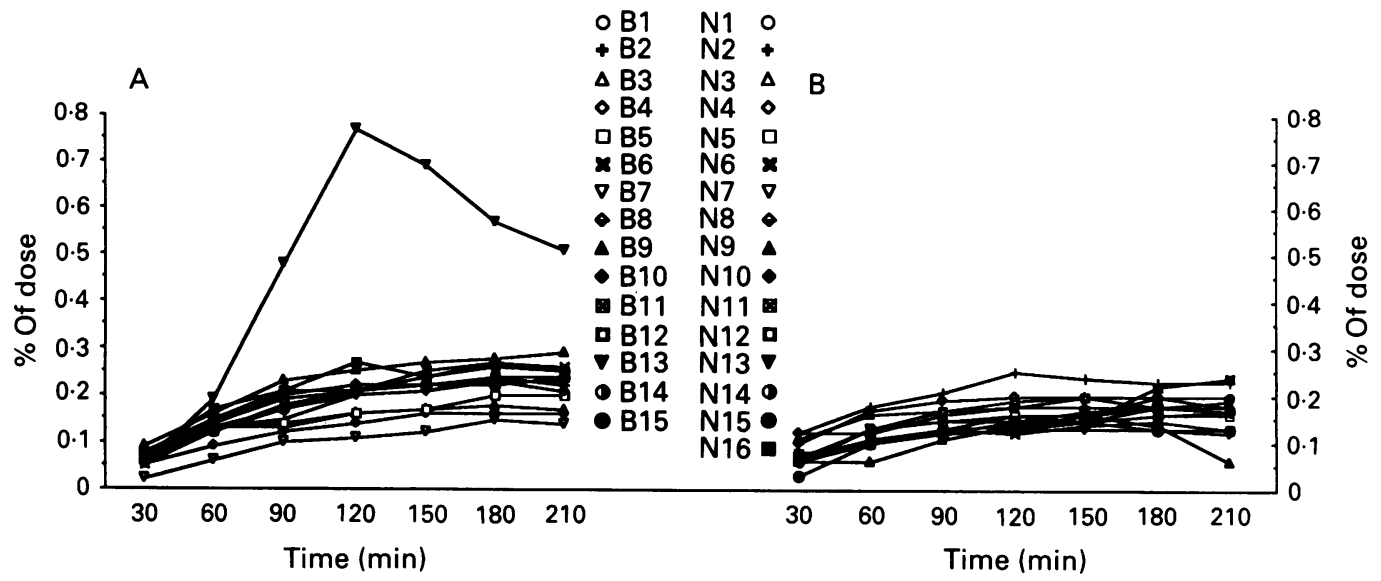

Figure 5: The percentage of a given dose of radioactivity $\left({ }^{1+} \mathrm{C}\right)$ expired at fixed time intervals after peroral intake of $10 \mu \mathrm{CC} i{ }^{14} \mathrm{C}$ $d$-Xylose in $(A) 15$ healthy old people $(B 1-B 15)$ and $(B) 16$ healthy young adults (NI-N16).

SERUM IMMUNOGLOBULINS

Fourteen subjects had serum IgA concentrations above the lower reference limit of $0.5 \mathrm{~g} / \mathrm{l}$, while one individual (B13) had IgA deficiency, as shown in the Table. All individuals had serum $\operatorname{IgM}$ (mean 0.9 (range 0.6 to $1.5 \mathrm{~g} / \mathrm{l}$ )) and serum IgG values (mean 12.5 (range $7 \cdot 1$ to $16 \cdot 5 \mathrm{~g} / \mathrm{l}$ ) within the normal reference limits.

\section{Discussion}

Fasting hypochlorhydria was prevalent in the healthy old people, and was accompanied by colonisation of the proximal gastrointestinal tract by microbes belonging to the indigenous flora of the upper respiratory tract and oropharynx. ${ }^{27}$ Principally, the same bacterial species were found that have previously been encountered, in low concentrations, in the proximal gut of normochlorhydric healthy adults. ${ }^{1-3}$

The most significant finding in the present study was the low frequency of Gram negative bacilli in gastric juice, despite advanced age and fasting hypochlorhydria. Correspondingly, the intraluminal bacterial metabolism of xylose was sparse, which strongly indicates that colonisation with URT flora, even at high counts, does not result in a positive ${ }^{14} \mathrm{C}-\mathrm{d}$ Xylose breath test. Patients with bacterial overgrowth usually expire significantly higher amounts of ${ }^{14} \mathrm{C}$, as indicated by the only subject with high counts of Gram negative bacilli in the stomach (B13).

Production of gas in Durham tubes discloses the ability to ferment glucose anaerobically to $\mathrm{H}_{2}$, $\mathrm{CO}_{2}$, and water vapour in vitro. ${ }^{28}$ In faecal samples $^{28}$ and in brush samples from the duodenum, ${ }^{29}$ this phenomenon was closely related to the presence of enterobacteriacea. Hence, the absence of gas in the samples from most old people in this study agrees with the results obtained by culture and the ${ }^{14} \mathrm{C}$ - $\mathrm{d}$ Xylose breath test. Furthermore, it shows the usefulness of this in vitro test for gastric aspirates, too. Small amounts of gas in some individuals without enterobacteriacea were probably caused by anaerobic fermentation by facultative species of the URT flora. The gas ratio discriminated well between these microbial sources of gas production, and may be a suitable way of identifying enterobacteriacea in aspirates from the upper gut.
Gianella et al ${ }^{1}$ examined nine hypochlorhydric subjects with a fasting $\mathrm{pH}>6$ and found a similar prevalence of Gram negative bacilli as in patients with pernicious anaemia. Information regarding the selection and clinical state of the hypochlorhydric individuals, however, is not given, ${ }^{1}$ and it is difficult to decide if they are comparable with our study group. In the present study, 10 individuals had a fasting $\mathrm{pH}>6$, and Gram negative bacilli in significant counts were not found among these (Table).

It is well established that oropharyngeal colonisation with Gram negative bacilli is associated with the severity of illness. ${ }^{30} \mathrm{In}$ a study of the $\mathrm{pH}$ and microflora of the gastric aspirates in normal subjects and those with diarrhoea in Brazil, malnutrition was associated with presence of Gram negative bacilli. ${ }^{31}$ The increase in $\mathrm{pH}$ in this group was comparable with the findings in a control group of breast fed children with normal flora, and the authors concluded that other factors besides $\mathrm{pH}$ regulate the growth of Gram negative bacilli. ${ }^{31}$ In achlorhydria accompanying pernicious anaemia, Stockbrugger et al found significant gastric amounts of $\mathrm{Gram}$ negative bacilli in 14 of 22 patients. ${ }^{8}$ In these patients, the clinical state may account for oropharyngeal colonisation that induces gastric overgrowth in the absence of the acid barrier. The combination of hypogrammaglobulinaemia and pernicious anaemia is well known, ${ }^{10}$ and concurrent immune deficiency may also contribute to the problem. ${ }^{810}$ Thus, even if fasting hypochlorhydria is a prerequisite for growth of Gram negative bacilli in the stomach, our data show that such colonisation is by no means a necessary consequence of a raised gastric $\mathrm{pH}$,even at advanced age. The low prevalence of oropharyngeal colonisation with Gram negative bacilli in healthy elderly people $(<10 \%)$ accords well with our findings. ${ }^{32}$

The hypochlorhydric stomach serves as a reservoir for microbes from saliva and ingested materials that continuously seeds the small intestine. With preserved migrating motor complexes, these microbes are transported aborally before significant multiplication takes place. ${ }^{33} \mathrm{~A}$ close relationship has been shown between intestinal stasis and bacterial overgrowth, ${ }^{3+}$ and impaired fasting motility of the small intestine has been reported in patients with bacterial overgrowth syndrome. ${ }^{35}$ In these disorders, 
ascending colonisation with Gram negative bacteria may occur, and preserved small intestinal motility during fasting seems to be an important factor in maintaining the microecological balance of the upper gut. ${ }^{35}$ Our healthy old people had migrating motor complexes that swept down the intestine at regular intervals, and the absence of intestinal colonisation with Gram negative bacilli was confirmed by the xylose breath test. The only individual with significant amounts of these bacilli (B13) had selective IgA deficiency combined with a modest increase in the gastric $\mathrm{pH}$ and borderline fasting small intestine motility, factors that suggest a multifactorial genesis. Even if patients with selective IgA deficiency usually have normal intestinal flora, ${ }^{11}$ the combination of this abnormality with impairment of other defence mechanisms aggravates bacterial colonisation. ${ }^{11}$

The influence of gastric acidity on the gastric microbial flora has also been studied in pharmacological models, using antacids, ${ }^{36}$ histamine blockers, ${ }^{36}$ and omeprazole. ${ }^{38}$ In healthy subjects, total bacterial counts increased because of colonisation with mainly Gram positive flora, ${ }^{36-38}$ in agreement with our findings. However, the gastric $\mathrm{pH}$ levels achieved in these pharmacological studies were lower than in the old people examined in the present study. ${ }^{36-38}$

The total concentration of gastric SCFAs was 10 to 15 times higher in the hypochlorhydric old people than in healthy young adults examined by the same technique. ${ }^{39}$ This probably reflects anaerobic metabolism in the stomach in vivo, and some contribution from swallowed saliva. ${ }^{39}$ The wide range of SCFA concentrations, unrelated to the type of flora, indicates that these metabolites are not reliable markers of gastric overgrowth with Gram negative bacilli flora in humans. Borellio et $a l^{40}$ did not find any SCFAs in gastric or jejunal aspirates from patients with hypogammaglobulinaemia and pernicious anaemia for reasons that remain unclear.

It must be emphasised that identification and quantification of microbes in samples from the intestinal tract can be problematic because of the complexity and interactions of the gut flora,${ }^{4}$ and the results are significantly influenced by the culturing technique. ${ }^{41}$ The present approach, including strict anaerobiosis, was chosen to yield a high recovery rate of enterobacteriacea and the bacteroides fragilis group, as tracers of lower gastrointestinal tract flora. The outcome of the ${ }^{14} \mathrm{C}$-d Xylose breath test renders false negative cultures, in this respect, less likely. Furthermore, plates were selected to favour growth of Haemophilus $s p$, in particular, and coagulase negative staphylococci, as tracers of upper respiratory tract flora. ${ }^{27}$

By continuous 24 hour recording, Fimmel et $a l^{42}$ showed that the average gastric $\mathrm{pH}$ is 1.98 (range 1.56 to 2.80 ), in healthy adults taking four meals. Thus, $\mathrm{pH}$ mediated control of microbial growth in the stomach will depend mainly on the fasting levels. The $\mathrm{pH}$ of fasting gastric juice is quite stable ${ }^{43}$ despite fluctuations in concert with the gastric component of the migrating motor complex, and also robust, showing little change as a result of the aspiration procedure, as found in the present study. Moreover, Stockbrugger $e t a l^{8}$ have shown a close correlation between bacterial counts and basal, but not peak, acid output. Hence, the $\mathrm{pH}$ in fasting aspirates reflects more directly the influence of gastric acid on microbial growth.

The criteria for hypochlorhydria varies as no consensus has been established. ${ }^{18}$ In fasting gastric aspirates, $\mathrm{pH} 3^{12}$ and $\mathrm{pH} 4$ are commonly used upper limits for healthy controls. Peterson et $a l^{43}$ performed gastric aspiration every half hour for 24 hours in eight individuals with preserved secretory capacity. During the nighttime the $\mathrm{pH}$ was mean 1.5 and only two readings showed values above $\mathrm{pH} 3$, and none above $\mathrm{pH}$ 4. ${ }^{43}$ Accordingly, $\mathrm{pH}>3$ applies well as criterion for fasting hypochlorhydria, even if vomiting occurs during the sampling procedure.

Our study indicates that about 3 of 4 healthy individuals above 80 years have fasting hypochlorhydria. The prevalence of achlorhydria was $17 \cdot 5 \%$ in a previous Scandinavian study on 348 patients between 70 and 89 years old with gastrointestinal disorders. ${ }^{\text {H }}$ A progressive increase in prevalence during this age is likely, and individuals with preserved ability to secrete acid in response to maximal stimulation may still have a considerably raised fasting $\mathrm{pH} .^{+5}$ This finding of Feldman $\mathrm{et}^{\mathrm{t} \mathrm{l}^{5}}$ represents an important objection against peak acid output as a criterion for hypochlorhydria in the present context. Bird et $a l^{46}$ examined 657 patients above 65 years by the azuresin test and found achlorhydria in $68 \%$ and hypochlorhydria in further $14 \%$, in accordance with our findings. Thus, the prevalence of hypochlorhydria is conditioned by the definition, and exceeds the current estimate of $20 \%$ considerably ${ }^{18}$ if it is based on a $\mathrm{pH}$ in fasting gastric apsirates. The present definition of fasting hypochlorhydria may be more relevant in studies on microbial growth.

The gastrin concentrations agree with previous findings in 1405 individuals aged 70,75 , and 79 years, ${ }^{25}$ but tend to be lower than those reported by Ganguli et al in hypochlorhydric individuals. ${ }^{47}$ The variable gastrin values may reflect the reduced capacity of the elderly oxyntic mucosa to secrete gastrin.

Fasting hypochlorhydria associated with gastric colonisation of microbes belonging to the oro- and nasopharyngeal flora is highly prevalent in healthy old people. These microecological changes may be largely attributed to the change in fasting gastric acidity, as small intestinal motility and immunoglobulins were normal. Old age per se does not result in colonisation with Gram negative bacilli, despite coexisting fasting hypochlorhydria.

This study was supported by grants for Nordic Gastroenterology from Smith Kline \& French AB, and Norwegian Medical Research Council.

1 Giannella RA, Broitman SA, Zamcheck N. Gastric acid barrier to ingested microorganisms in man: studies in vivo and in vitro. Gut 1972; 13: 251-6.

2 Drasar BS, Shiner M, Mcleod GM. Studies on the intestinal flora. The bacterial flora of the gastrointestinal tract in healthy and achlorhydric persons. Gastroenterology 1969; 56: 71-9.

3 Gorbach LS, Plaut AG, Nahas L, Weinstein L. Studies of intestinal microflora. II. Microorganisms of the small intestine and their relations to oral and fecal flora. Gastroenterology 1967; 53: 856-67.

4 Finegold FM, Sutter VL, Mathisen GE. Normal indigenous intestinal flora. In: Hentges DJ, ed. Human intestinal flora in health and disease. New York: Academic Press, 1983: 33-54. 
5 Thulig B. Impact of anaesthetic procedures on the oropharyngeal and gastrointestinal defence against carriage. In: Stoutenbeek CP, Van Saene HK, eds. Infection and the anaesthetist. Clinical anaesthesiology No 5. London: Bailliere, 1991: 27-38.

6 Muscroft TJ, Deane SA, Young D, Burdon DW, Keighley MRB. The microflora of the postoperative stomach. BrF Surg 1981; 68: $560-4$.

7 Allan JD, Shiner M. Influence of gastric $\mathrm{pH}$ on gastric and jejunal flora. Gut 1967; 8: 574-81.

8 Stockbruegger RW, Cotton PB, Menon GG, Beilby JOW, Bartholomew BA, Hill MJ, et al. Pernicious anaemia, intragastric bacterial overgrowth, and possible conseintragastric bacterial overgrowth, and possi

9 Browning GG, Buchan KA, Mackay C. The effect of vagotomy and drainage on the small bowel flora. Gut 1974; 15: and draina $139-42$.

10 Dolby JM, Webster ADB, Borriello SP, Barclay FE, Bartholomew BA, Hill MJ. Bacterial colonisation and nitrit concentration in the achlorhydric stomachs of patients with primary hypogammaglobulinaemia of classic pernecious anaemia. Scand $\mathcal{F}$ Gastroenterol 1984; 19: 105-10.

11 Macloughlin GA, Hede JE, Temple JG, Bradley J, Capman $\mathrm{DM}, \mathrm{McF}$ arland $\mathrm{J}$. The role of IgA in the prevention of bacterial colonisation of the jejunum in the vagotimized subject. Br $\mathcal{F}$ Surg 1978; 65: 435-7.

12 Siurala M, Isokoski M, Varis K, Kekki M. Prevalence of gastritis in a rural population. Scand $\mathcal{F}$ Gastroenterol 1968; 3 : 211-23.

13 Vanzant FR, Alvarez WC, Eusterman GB, Dunn HL, Berkson $\mathrm{J}$. The normal range of gastric acidity from youth to old age. Arch Intern Med 1932; 49: 345-59.

14 Moore JG, Tweedy C, Christian PE, Datz FL. The effect of age on gastric emptying of liquid-solid meals in man. Dig Dis Sci 1983; 28: 340-4.

15 Horovitz M, Maddern GJ, Chatterton BE, Collins PJ, Hardin $\mathrm{PE}$, Shearman DJC. Changes in gastric emptying rates with age. Clin Sci 1984; 67: 213-8.

16 Simon GL, Gorbach SL. Intestinal flora in health and disease. Gastroenterology 1984; 86: 174-93.

17 Roberts SH, James O, Jarvis EH. Bacterial overgrowth syndrome without blind loop: a cause for malnutrition in the elderly. Lancet 1977; ii: 1193-5.

18 Holt PR, Rosenberg IH, Russell RM. Causes and consequences of hypoclorhydria in the elderly. Dig Dis $S_{c i} 1989$ quences of

19 Engedal K, Gilje K, Laake K. Prevalence of dementia in Norwegian sample aged 75 years and over and living at home. Comp Gerontol A 1988; 2: 1-5.

20 Husebye $E$, Engedal $K$. The patterns of motility are maintained in the human small intestine through the process of ageing. Scand F Gastroenterol 1992; 27: 397-404.

21 Gustafsson BE, Midtvedt T, Norman AJ. Isolated fecal microorganisms capable of $7 \alpha$-dehydroxylating bile acids. f Exp Med 1966; 123: 413-32.

22 Skar V, Larsen S, Osnes M. The l-g ${ }^{1+} \mathrm{C}-\mathrm{d}$-Xylose breath test in gallstone patients with and without duodenal diverticula. $S$ cand $\mathcal{F}$ Gastroenterol 1985; 20: 447-51.

23 Høverstad T, Fausa O, Biørneklett A, Bøhmer T. Short chain fatty acids in normal human feces. Scand $\mathcal{f}$ Gastroenterol fatty acids in no

24 Husebye E, Skar V, Aalen OO, Osnes M. Digital ambulatory manometry of the small intestine in healthy adults: Estimates of the variation within and between individuals and statistical management of incomplete MMC periods. Dig Dis Sci 1990; 35: 1057-65.

25 Lindstedt G, Olbe L, Kilander AF, Armbrecht U, Jagenburg $\mathrm{R}$, Rundsteen $\mathrm{D}$, et al. Analytical and clinical evaluation of radioimmunoassay for gastrin. Clin Chem 1985; 31: 76-82.

26 Bland JM, Altman DG. Statistical methods for assessing agreement between two methods of clinical measurement. Lancet 1986; i: 307-10.
27 Liljemark WF, Bloomquist CG. Normal microbial flora of the human body. In: Newman MG, Nisengard R, eds. Oral microbiology and immunology. Philadelphia: W B Saunders, 1988: $140-2$.

28 Bjørneklett A, Midtvedt T. Influence of three antimicrobia agents - penicillin, metronidazole, and doxycyclin - on the intestinal microflora of healthy humans. Scand $\mathcal{F}$ Gastroenterol 1981; 16: 473-80.

29 Skar V, Skar AG, Osnes M. The duodenal bacterial flora in the region of papilla of vater in patients with and without duodenal diverticula. Scand 7 Gastroenterol 1989; 24 649-56.

30 Johanson WG, Pierce AK, Sanford JP. Changing pharyngeal bacterial flora of hospitalized patients. N Engl F Med 1969, 281: $1137-40$.

31 Maffei HVL, Norbrega FJ. Gastric pH and microflora of normal and diarrhoeic infants. Gut 1975; 16: 719-26.

32 Spijkervet FK, van .Saene HKF, Panders AK, Vermey A Colonization index of the oral cavity: novel technique for monitoring colonisation defences. Microb Ecol Health Dis 1989; 2: 145-51.

33 Dixon JMS. The fate of bacteria in the small intestine. 7 Patho Bacteriol 1960; 79: 131-40.

34 Frederiksen W, Bruusbaard A, Hess Thaysen E. Assessment of the relationship between gastric secretory capacity and jejunal bacteriology. Scand f Gastroenterol 1973; 8: 353-9.

35 Vantrappen G, Janssens J, Hellemans J, Ghoos Y. The interdigestive motor complex of normal subjects and interdigestive motor complex of normal subjects and patients with bacterial overgro

36 Snepar R, Poporad GA, Romano JM, Kobasa WD, Kaye D. Effect of cimetidine and antacid on gastric microbial flora. Infect Immun 1982; 36: 518-24.

37 Milton-Thompson GJ, Lightfoot NF, Ahmet Z, Hunt RH Barnard J, Brimblecombe RW, et al. Intragastric acidity, bacteria, nitrite, and $\mathrm{N}$-nitroso compounds before, during, and after cimetidine treatment. Lancet 1982; i: 1091-5.

38 Sharma BK, Santana IA, Wood EC, Walt RP, Pereira M, Noone $P$, et al. Intragastric bacterial activity and nitrosation before, during, and after treatment with omeprazole. $B M \mathcal{F}$ 1984; 289: 717-9.

39 Høverstad T, Biørneklett A, Midtvedt T, Fausa O. Short chain fatty acids in the proximal gastrointestinal tract of healthy subjects. Scand 7 Gastroenterol 1984; 19: 1053-8.

40 Borriello SP, Reed PJ, Dolby JM, Barclay FE, Webster ADB Microbial and metabolic profile of achlorhydric stomach: comparison of pernicious anaemia and hypogammaglobulinaemia. F Clin Pathol 1985; 38: 946-53.

41 Clarke RTJ, Beauchop T. Methods for studying gut microbes. In: Clarke RTJ, Beauchop T, eds. Microbial ecology of the gut. London: Academic Press, 1977: 1-33.

42 Fimmel CJ, Etienne A, Cilluffo T, Ritter C, Gasser T, Rey JP et al. Long-term ambulatory gastric $\mathrm{pH}$ monitoring: validation of a new method and effect of $\mathrm{H}_{2}$-antagonists. Gastroenterology 1985; 88: 1842-51.

43 Peterson WL, Barnett C, Feldman M, Richardson CT. Reduction of twenty-four-hour gastric acidity with combination of drug therapy in patients with duodenal ulcer. Gastroenterology 1979; 77: 1015-20.

44 Christiansen PM. The incidence of achlorhydria and hypochlorhydria in healthy subjects and patients with gastrointestinal diseases. Scand F Gastroenterol 1968; 3: 497-508.

45 Feldman $M$, Barnett $\mathrm{C}$. Fasting gastric $\mathrm{pH}$ and its relationship to true hypochlorhydria in humans. Dig Dis Sci 1991; 36 . 866-9.

46 Bird T, Hall MRP, Schade ROK. Gastric histology and its relation to anaemia in the elderly. Gerontology 1977; 23: 309-21.

47 Ganguli PC, Cullen DR, Irvine WJ. Radioimmunoassay of plasma-gastrin in pernicious anaemia, achlorhydria without pernicious anaemia, hypochlorhydria, and in controls. pernicious anaemia, 